\title{
AKUISISI DATA SUMBERDAYA AIR TANAH DI DAERAH SUKODONO KABUPATEN PACITAN
}

\author{
Teguh Prayogo \\ Peneliti Bidang Geografi Fisik, Pusat Teknologi Sumbrdaya Mineral, Deputi TPSA, BPP Teknologi \\ JI. MH. Thamrin No. 8 Jakarta Pusat
}

\begin{abstract}
The need of water for human life is very high, especially to meet a demand of water supply, such as for drinking water, washing, taking a bath, and etc. Unfortunately, the availability of surface water at an area is sometimes not enough to comply with a request of pure water, as happened in the Sukodono area. Hence, to avoid the problem, we focus at the ground water sources as alternative water supply. In this paper will be discussed exploration of ground water that is accomplished with imaging resistivity technology to find out characteristic and condition of ground water in Sukodono, Pacitan district, East Java Province. Based on the result of survey in field and interpretation, the existence of aquifer in Sukodono area is occupied between 5 - 40 meter depth.
\end{abstract}

Key words : ground water, imaging resistivity, desa Sukodono

\section{PENDAHULUAN}

\subsection{Latar Belakang}

Kabupaten Pacitan termasuk Propinsi Jawa Timur bagian selatan dengan luas total daratan sekitar 1.419,44 Km². Kabupaten Pacitan ini terletak disebelah Barat Daya Propinsi Jawa Timur yang berbatasan dengan Propinsi Jawa Tengah. Terletak diantara $07,550^{\circ}$ sampai $8,170^{\circ}$ Lintang Selatan dan $110,550^{\circ}$ sampai $111,250^{\circ}$ Bujur Timur 1). Kabupaten Pacitan dibatasi oleh :

- Utara : Kab.Ponorogo (Jawa Timur), Kab.Wonogiri (Jawa Tengah)

- Timur : Kab.Trenggalek (Jawa Timur)

- Selatan : Samudra Indonesia

- Barat : Kab.Wonogiri (Jawa Tengah)

Sebagian besar terdiri atas pertanian tanah kering sekitar $1.124,00 \mathrm{~km}^{2}$, daerah persawahan sekitar $111,32 \mathrm{Km}^{2}$, pemukiman atau kampung sekitar $111,72 \mathrm{~km}^{2}$, perkebunan sekitar 14,94 $\mathrm{Km}^{2}$, kawasan hutan sekitar 24,94 $\mathrm{Km}^{2}$, sedangkan selebihnya berupa kebun campur, tanah tandus dan lain-lain.

Salah satu problema di kabupaten Pacitan, terutama bagian barat adalah sulitnya mendapatkan air tanah. Hal ini terjadi karena sebagian besar wilayah tersebut tertutup oleh (covered by) batugamping (batukapur). Di daerah batugamping, air tanah tersimpan dalam suatu konduit yang berupa rekahan batugamping , rongga-rongga batugamping atau sungai bawah tanah. Untuk mengatasi problem kesulitan air, maka dilakukan pekerjaan penyelidikan dan pengembangan sumberdaya air bawah tanah. Adapun pekerjaannya terdiri dari pemetaan potensi air tanah, dan kedalaman air tanah.

Metoda imaging resistivity merupakan salah satu metoda geofisika dinamis yang dikembangkan untuk mendeteksi kondisi bawah permukaan hingga kedalaman 100 meter. Salah satu metoda resistivity yang diterapkan pada survei ini adalah metoda pole-dipole. Menggunakan metoda ini, diharapkan bentukbentuk saluran air (konduit) di batugamping dan bentuk gua, dapat diidentifikasi dengan baik.

Pengukuran resistivity ini dilakukan di Daerah Kotlik, Desa Sukodono, Kecamatan Donorejo, Kabupaten Pacitan. Disamping pengukuran resistivity, dilakukan juga pengamatan geohidrologi di sumur ataupun mata air yang terdapat di sekitar titik pengukuran resistivity. Interpretasi keberadaan konduit dibuat berdasarkan semua data yang terkumpul. Setelah interpretasi selanjutnya diberikan rekomendasi untuk melakukan pemboran pada titik-titik yang mempunyai potensi keberadaan akuifer.

\subsection{Tujuan}

Tujuan dari penelitian ini adalah menerapkan metode imaging resistivity dengan tujuan untuk keperluan akuisisi data guna penyelidikan dan pengembangan sumberdaya air bawah tanah di Daerah Sukodono, Kabupaten Pacitan, Jawa Timur.

\section{LOKASI PENELITIAN DAN KESAMPAIAN DAERAH}

Penelitian ini dilakukan di daerah Kotlik, Desa Sukodono, kecamatan Donorojo, Kabupaten Pacitan Bagian Barat, dimana kabupaten Pacitan termasuk Propinsi Jawa Timur bagian selatan dengan luas total daratan sekitar 1.419,44 $\mathrm{Km}^{2}$. Kabupaten Pacitan ini terletak di sebelah Barat Daya Propinsi Jawa 
Timur yang berbatasan dengan Propinsi Jawa Tengah. Terletak diantara $07,550^{\circ}$ sampai $8,170^{\circ}$ Lintang Selatan dan $110,550^{\circ}$ sampai $111,250^{\circ}$ Bujur Timur.

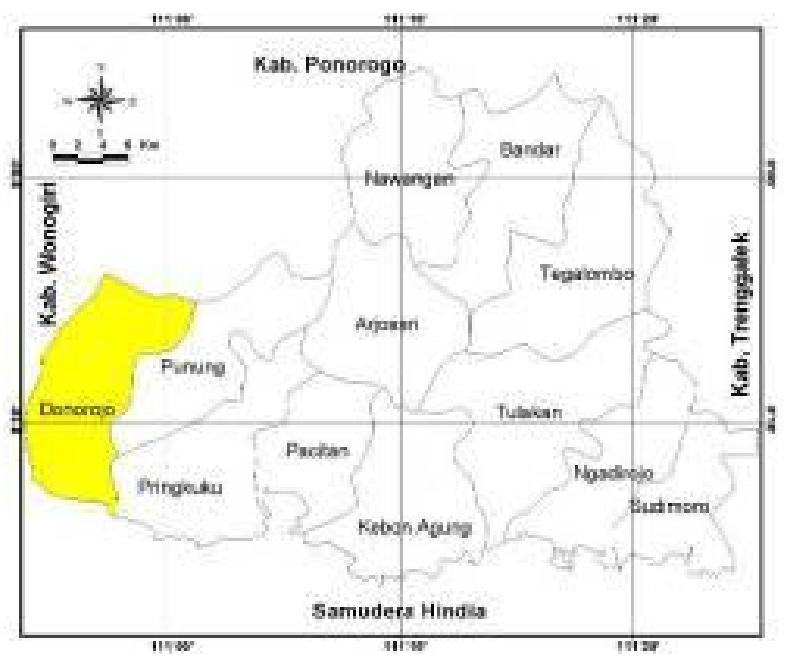

Gambar 1. Lokasi Penelitian

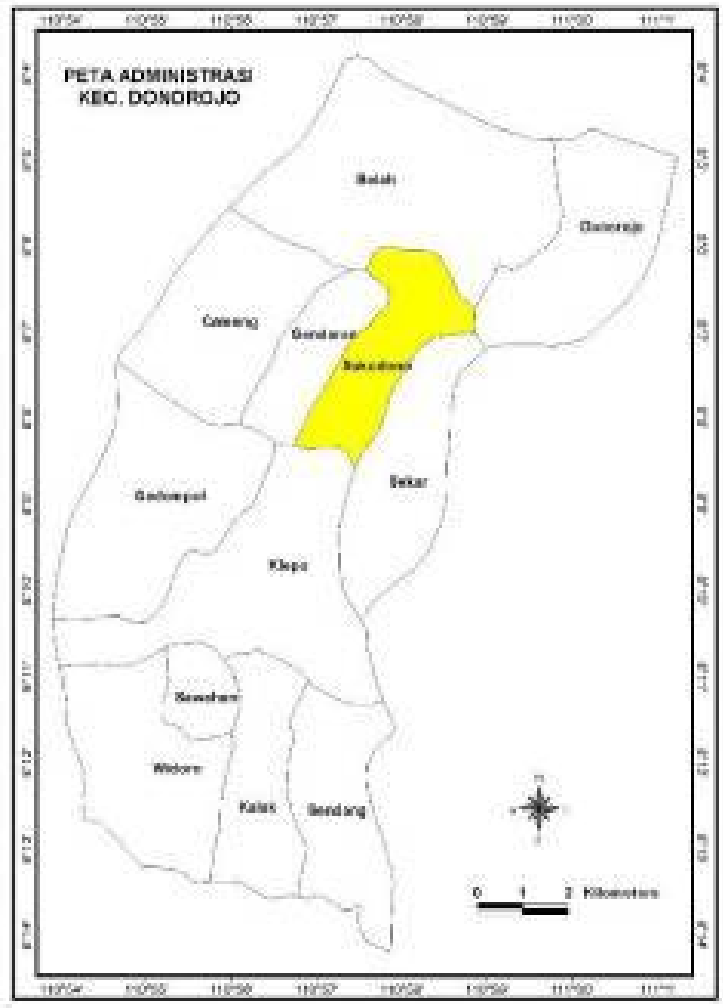

Gambar 2. Peta Administrasi Daerah Donorojo

Pencapaian daerah penelitian dapat dicapai dengan kendaraan roda empat atau mobil dimana telah tersedia akses jalan utama yang membelah kecamatan menjadi dua bagian. Jalan ini merupakan kelanjutan jalan potong dari jalur utama Pacitan-Solo. Jalan ini melewati Desa Belah, Desa Sukodono, Desa Klepu dan sampai
Desa Kalak. Sarana Transportasi umum berupa mobil omprengan. Di samping itu terdapat jalan yang membelah kecamatan dari sebelah timur ke barat menhubungkan antara ibu kota Pacitan dan Kabupaten Wonogiri hingga Yogyakarta.

\section{METODOLOGI}

Metodologi yang diterapkan dalam penelitian ini secara garis besar terdiri dari studi pendahuluan, survei lapangan yang meliputi pengamatan sumur dan survei imaging resistivity, dan analisis.

\subsection{Studi Pendahuluan}

Studi Pendahuluan ini dilaksanakan dengan melakukan kegiatan tinjauan pustaka, menginventarisasi data dan informasi, mempersiapkan peta-peta dasar kerja, dan penentuan rencana survei (mobilisasi tim dan peralatan).

\subsection{Survei Lapangan}

Survei lapangan ini meliputi pekerjaan survei imaging resistivity yang dibantu dengan pengamatan sumur gali penduduk.

Survei imaging resistivity ini merupakan salah satu metoda geofisika dinamis yang dikembangkan untuk mendeteksi kondisi bawah permukaan (kebradaan akuifer) dengan menginjeksikan arus kedalam bumi, selanjutnya di permukaan bumi diukur nilai kuat arus (I) dan beda potensial $(\mathrm{V})$ titik-titik injeksi arus tersebut.

\subsection{Analisis}

Pekerjaan analisis ini dilakukan untuk memberikan gambaran tentang keberadaan akuifer dengan pemodelan dan interpretasi hasil survei lapangan di daerah penelitian.

\section{GEOLOGI DAERAH PENELITIAN}

Daerah penelitian secara umum sebagai Lajur Pegunungan Selatan Jawa Timur. Morfologinya sebagian besar didominasi oleh satuan morfologi kars dan sebagian kecil satuan dataran aluvial 3). Satuan geomorfologi kars mencakup hampir 98\% daerah penyelidikan dicirikan oleh lamparan berbentuk Plateau batugamping yang mempunyai topografi kars. Gejala kars ini ditunjukkan oleh adanya gua batugamping, aliran sungai bawah tanah, dolina dan ovala.

Bukit-bukit kecil menjulang antara 20 50 meter di atas muka laut merupakan bentukan hasil erosi, yang umumnya disusun oleh batugamping terumbu. Bentuk bukitnya seperti 
kerucut, kerucut terpancung, meja, tabung dan sebagainya yang dipengaruhi oleh ragam batugamping penyusunnya. Wilayah perbukitan ini dikenal sebagai Pegunungan Sewu. Sungai besar yang memotong satuan ini adalah Sungai Baksoka dan Sungai Barong yang kelurusaanya dipengaruhi oleh struktur rekahan dan retakan. Satuan dataran aluvial yang disusun oleh batuan aluvial sebarannya sangat terbatas, yaitu di sepanjang aliran sungai besar.

\section{PERALATAN YANG DIGUNAKAN}

Peralatan yang digunakan pada penelitian ini terdiri dari Global Positioning System (GPS), Kompas Geologi, Meteran, Digital Camera, dan Resistivitymeter merk OYO tipe Mc.Ohm 2115 A, elektroda dan geoscaner 1803, serta peralatan penunjang lainnya.

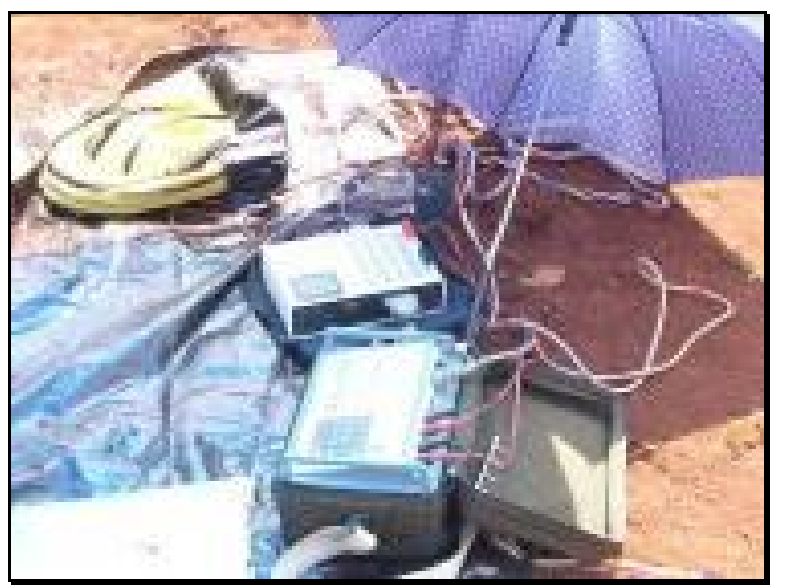

Gambar 3. Peralatan imaging resistivity

\section{HASIL DAN PEMBAHASAN}

Pada penelitian air tanah di daerah Sukodono ini, konfigurasi (susunan) elektroda arus dan potensial pada geolistrik pada survey imaging resistivity adalah konfigurasi 2D, dimana hasilnya akan memberikan gambaran dalam 2 dimensi. Persamaan $\quad \rho a=\pi . n(n+1) \cdot l \cdot R$ digunakan untuk mengolah data hasil pengukuran geolistrik 2D ${ }^{3}$ ). Hasil perhitungan menggunakan persamaan tersebut baru menghasilkan nilai tahanan jenis dan kedalaman semu. Untuk mendapatkan nilai tahanan jenis dan kedalaman sebenarnya, selanjutnya dipakai pemodelan inversi 2D.

Jumlah lintasan/penampang yang diperoleh dari hasil pengukuran adalah 6 (enam) lintasan. Semua lintasan ini terdapat di Kecamatan Donorejo.

Pengukuran antara lain dilakukan di dekat mata air yang terdapat di desa Kotlik, selanjutnya dilakukan pengukuran di darah lainnnya di sekitar mata air. Tujuan pengukuran ini adalah untuk menelusuri conduit tempat mengalirnya mata air tersebut. Di dekat Polindes dilakukan 4 pengukuran, sedangkan dua lintasan lainnya dilakukan di pemukiman yang berjarak kurang lebih $1 \mathrm{~km}$ dari polindes. Di lokasi ini terdapat bekas sumur penduduk yang kering. Dilakukan pengukuran di sini juga untuk mengetahui keberadaan conduit.

Setelah data pengukuran terkumpul, selanjutnya dilakukan pemodelan menggunakan software pemodelan Res2Dinv. Hasil pemodelan berupa penampang resistivity, yang selanjutnya dipakai untuk interpretasi keberadaan lapisan yang menyimpan air.

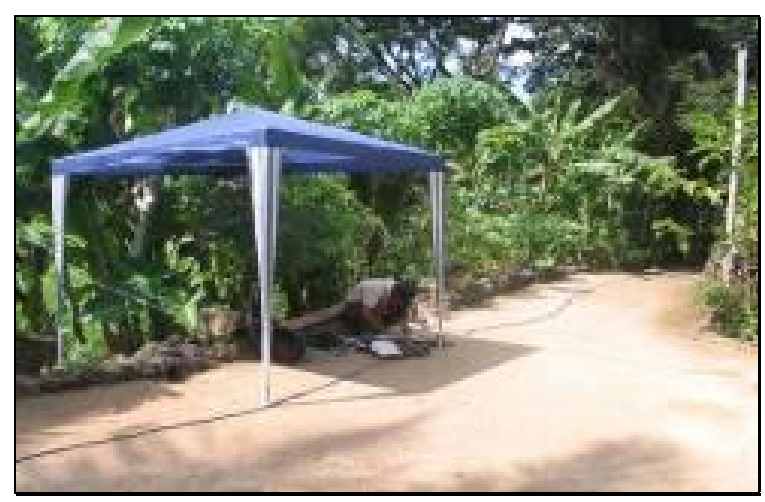

Gambar 4. Pengukuran tahanan jenis di depan POLINDES (Poliklinik Desa) Dusun Kotlik, Daerah Sukodono

Pekerjaan pengukuran tahanan jenis pada lintasan 01 dilakukan di depan POLINDES (Poliklinik Desa) Dusun Kotlik yang berarah relatif utara - selatan dan dengan spasi elektroda $10 \mathrm{~m}$, seperti terlihat pada Gambar $4 \mathrm{di}$ atas.

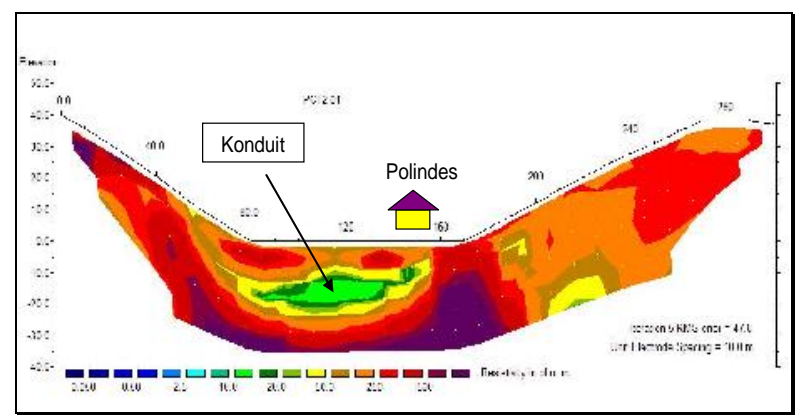

Gambar 5. Hasil pemodelan tahanan jenis di lintasan 01

Hasil akuisisi data tahanan jenis pada lintasan $01 \mathrm{di}$ depan POLINDES tersebut memberikan nilai tahanan jenis berkisar antara $10 \mathrm{ohmm}$ hingga > $1500 \mathrm{ohmm}$. Berdasarkan hasil pemodelan pada Gambar 5 di atas, maka kisaran nilai tahanan jenis $10-20$ ohmm 
diinterpretasikan sebagai conduit (perhatikan gambar) dengan kedalaman antara $15-20$ meter.

Melihat kenampakan pada Gambar 5 di atas terlihat bahwa conduit tersebut mempunyai dimensi yang cukup besar dengan pelamparan horisontal sekitar > 50 meter yang merupakan daerah potensi akuifer. Oleh karena itu apabila akan dilakukan pencarian air, pekerjaan pemboran di sarankan pada daerah ini.

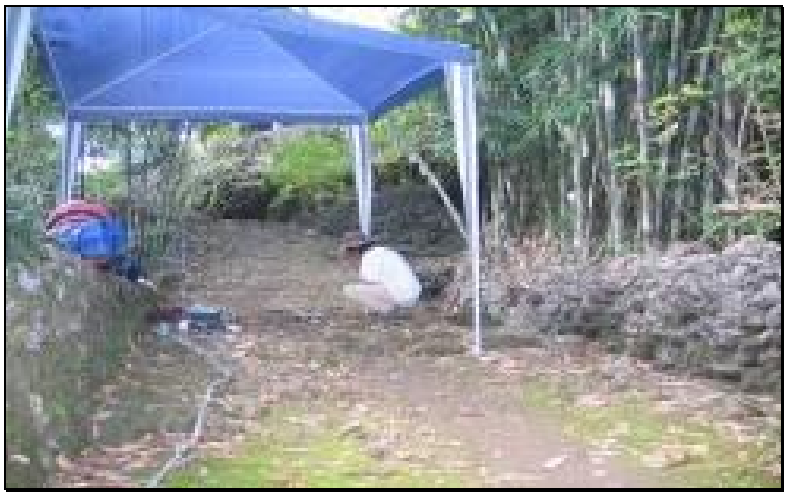

Gambar 6. Pengukuran tahanan jenis pada lintasan 02 di sebelah timur lintasan 01

Gambar 6 menunjukkan proses pengukuran tahanan jenis yang kedua pada lokasi sebelah timur dari lintasan 01, dimana pada lokasi lintasan 02 ini terdapat mata air. Lintasan 02 ini sejajar dengan lintasan 01 dimana arah lintasannya brah utara - selatan dengan spasi elektroda $10 \mathrm{~m}$.

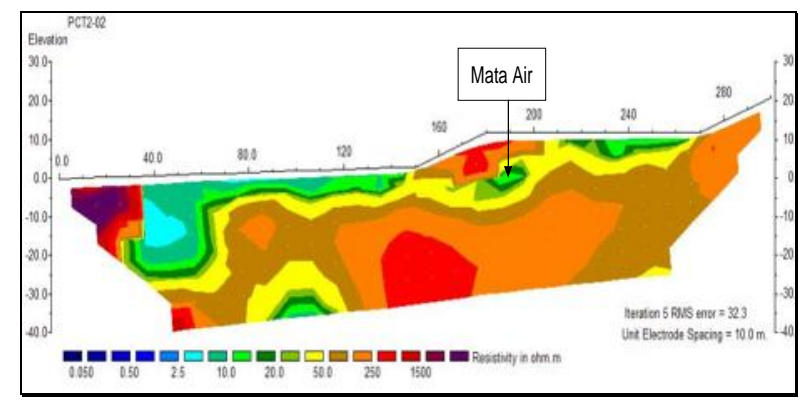

Gambar 7. Hasil Pemodelan di lintasan 02

Pada Gambar 7 di atas merupakan penampang tahanan jenis hasil dari proses pemodelan di lintasan 02 dengan kedalaman sekitar 40 meter. Penampang ini melintas di sekitar mata air (perhatikan gambar). Di samping lokasi tempat terdapatnya mata air, terdapat juga indikasi lahan dolina. Lahan ini mempunyai batuan yang lebih lunak di banding batugamping. Kisaran nilai tahanan jenis daerah dolina dan juga kisaran rho untuk air relative sama yakni sekitar 10 - 20 ohmm. Yang membedakan dolina dengan kisaran rho untuk air adalah : dolina terdapat di permukaan sedangkan air terdapat di bawah permukaan, dimana kedudukan mata air pada daerah lintasan 02 ini berada pada kedalaman sekitar $4 \mathrm{~m}$.

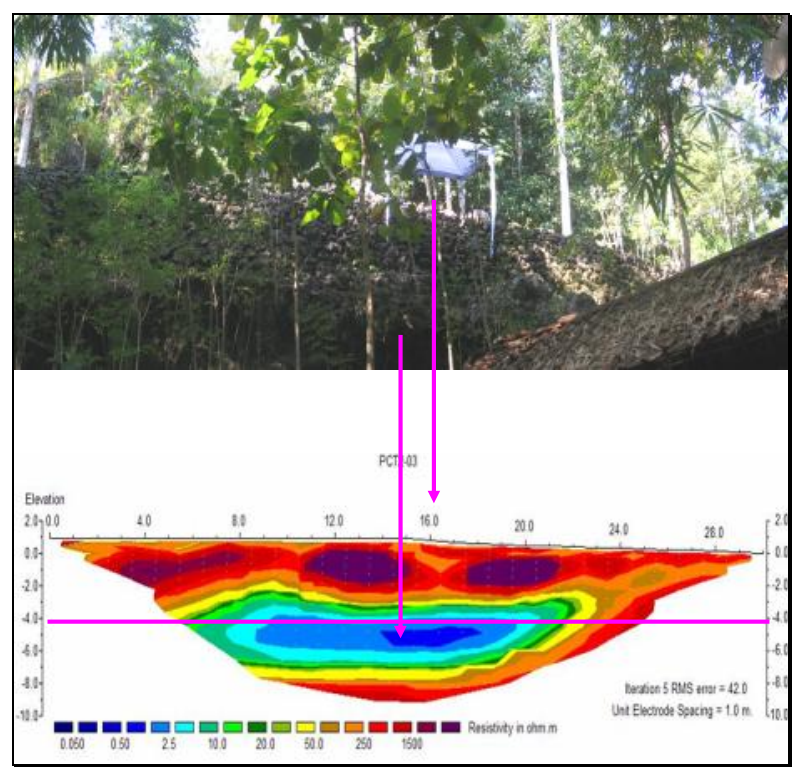

Gambar 8. Pengukuran dan pemodelan tahanan jenis di di atas mata air

Gambar 8 memperlihatkan pengukuran tahanan jenis yang dilakukan di atas tebing tempat terdapatnya mata air di Dusun Kotlik. Spasi elektroda yang dipakai = 1 meter, dengan demikian kedalaman penetrasi maksimal adalah 10 meter. Dari permukaan tanah tempat pengukuran dilakukan (perhatikan tenda biru pada foto di atas), mata air terdapat pada kedalaman 4 meter. Pada penampang geolistrik tersebut di atas terlihat bahwa mata sir terindikasi dengan nilai tahanan jenis $0.50 \mathrm{ohmm}$ hingga 20 ohmm. Kisaran nilai rho inilah yang selanjutnya dipakai untuk mengidentifikasi conduit berisi air di daerah Kotlik ini.

Berdasarkan hasil akuisisi data tahanan jenis dan pemodelannya seperti yang telah dibahas di atas, maka dapat diinterpretasikan bahwa terdapat jenis-jenis saluran air di daerah survei yaitu berbentuk rongga bawah permukaan dengan diameter berkisar antara 5 meter hingga 20 meter lebih dengan kedalaman berkisar dari 6 meter hingga 40 meter. Saluran ini umumnya tidak berhubungan antara satu dan lainnya.

Mencermati hasil survei dan pengolahan data secara umum, maka potensi air bawah tanah yang didapatkan pada daerah survey umumnya berupa saluran atau kantung-kantung yang tidak terlalu besar. Oleh karena itu, apabila akan dimanfaatkan untuk memenuhi kebutuhan air bersih bagi masyarakat, cakupannya tidaklah terlalu luas dan tidak bisa untuk sekala yang 
besar, akan tetapi cukup untuk beberapa KK (Kepala Keluarga) saja.

Mengacu pada hal di atas, maka rekomendasi yang bisa diberikan adalah pemboran eksploitasi bisa dilakukan pada saluran air yang tidak terlalu dalam (maksimal 20 meter), dimana jumlah pemborannya banyak. Untuk satu desa misalnya, seharusnya dilakukan 2 atau 3 atau bahkan lebih pemboran. Dengan demikian kebutuhan air bersih tidak mengandalkan hanya pada satu sumur saja. Dengan maksimal kedalaman yang hanya 20 meter maka untuk menyedot air ke permukaan dapat dipergunakan pompa manual (bukan listrik). Penyedotan air menggunakan pompa listrik memerlukan biaya operasional serta perawatan yang cukup besar. Kalau ini diterapkan, umumnya tidak akan bertahan lama karena masyarakat desa setempat tidak mampu untuk membiayainya.

Berdasarkan hasil interpretasi dan pertimbangan-pertimbangan diatas, maka tempat-tempat yang potensial untuk dilakukan pemboran adalah sebagai berikut :

\begin{tabular}{|l|l|c|}
\hline Kode Lokasi & Posisi Titik Bor & Kedalaman \\
\hline lintasan-01 & $\begin{array}{l}\text { Meter ke } 120 \\
\text { (40 m sebelah } \\
\text { selatan polindes) }\end{array}$ & 20 meter \\
\hline
\end{tabular}

\section{KESIMPULAN}

Berdasarkan hasil akuisisi data tahanan jenis di lapangan, pemodelan dan analisis di daerah Sukodono Kabupaten Pacitan, maka secara garis besar dapat disimpulkan sebagai berikut :

- Indikasi adanya konduit (saluran) air di daerah penelitian ditandai dengan adanya anomali nilai resistivity (tahanan jenis), dengan kisaran nilai $15-20$ ohmm.

- Anomali dengan nilai resistivity 30 - 50 ohmm diperkirakan merupakan saluran air dengan jumlah air yang sedikit.

- Anomali lainnya adalah gua bawah tanah, yang mempunyai indikasi nilai resistivity di atas 1000 ohmm.

- Dari hasil pemodelan dan interpretasi, maka didapatkan bahwa air tanah (aquifer) di daerah survei semuanya tersimpan dalam bentuk konduit kars, yang kedalamannya berkisar antara 5 meter hingga 40 meter.

- Apabila akan dilakukan pemboran eksploitasi, maka dapat dilakukan di sebelah selatan Polindes dengan kedalaman $20 \mathrm{~m}$.

- Perlunya penerapan teknologi Imaging Resistivity ini dilakukan dibeberapa daerah yang mengalami kesulitan air, sehingga ikut membantu menanggulangi permasalahan tersebut.

\section{DAFTAR PUSTAKA}

$1 . \quad$, 2003, "Kabupaten Pacitan Dalam Angka 2003", Badan Pusat Statistik Kabupaten Pacitan, Badan Perencanaan Pembangunan Daerah.

2. Edwards L.S., 1977, “ $A$ modified pseudosection for resistivity and inducedpolarization. Geophysics", 42, 1020-1036.

3. Samodra H., Gafoer S., Tjokrosapoetro S., 1992, "Peta Geologi Lembar Pacitan, Jawa Skala 1 : 100.000", Pusat Penelitian dan Pengembangan Geologi, Direktorat Jendral Geologi dan Sumberdaya Mineral, Departemen Pertambangan dan Energi. 